\title{
Jan Paweł II, który zmienił oblicze świata
}

Zacznę od pytania: Czy Jan Paweł II zamierzał zmienić oblicze świata? Znamy drogę jego życia, które rozpoczęło się w spokojnych Wadowicach, półtora roku po zakończeniu krwawego konfliktu, nazwanego I wojną światową. Dziewiętnaście lat później młody student Uniwersytetu Jagiellońskiego zaczął osobiście doświadczać, czym jest brutalna przemoc zrodzona z obłąkanej ideologii nazistowskiej. W tym czasie Karol Wojtyła został zmuszony, by zdobywanie wiedzy w auli uniwersyteckiej zamienić na pracę w krakowskim kamieniołomie. Jednocześnie w tym trudnym okresie podjął fundamentalną decyzję wkroczenia na drogę powołania kapłańskiego. Tak odczytał swoje miejsce w świecie, w którym toczy się walka między dobrem i złem, między miłością i nienawiścią, między cywilizacją życia i śmierci. Wybór był oczywisty. Zaczął od siebie. Przygotowywał umysł i serce, by pójść za Jezusem i służyć Mu w Kościele w najważniejszej sprawie zbawienia świata. To był horyzont jego wiary, nadziei i miłości.

Droga kapłańskiego życia Karola Wojtyły, które stało się istotnym rysem jego tożsamości, stanowi przykład człowieka obarczanego coraz większą odpowiedzialnością w Kościele. Tak było przy jego nominacji na biskupa pomocniczego, a następnie metropolitę krakowskiego i kardynała. Wybór dokonany czterdzieści lat temu w kaplicy Sykstyńskiej pieczętował lata pasterskiej posługi kapłana, biskupa i kardynała, który pełnił posłannictwo w konfrontacji z totalitarnym systemem komunistycznym, z gruntu wrogim wobec wiary i Kościoła. Taki był wtedy świat, podzielony między zwalczające się potęgi. A także - jak zawsze w historii - był to i jest świat dobra i zła, świat wiary i niewiary, świat ubóstwa jednych i bogactwa drugich. 
16 października 1978 roku nowo wybrany Biskup Rzymu i Papież musiał jeszcze bardziej poszerzyć przestrzeń swego serca, by znalazły w nim miejsce wszystkie narody, kultury i tradycje, a więc bez wyjątku cały świat. Kto śledził z bliska pontyfikat Jana Pawła II, zdawał sobie sprawę, że poczuwa się on do odpowiedzialności nie tylko za Kościół, ale za losy całej ludzkości. Tak było od początku i do końca. Oczywiście, Jan Paweł II musiał się uczyć świata, poznawać z bliska jego problemy na wszystkich kontynentach, ale - jak wiemy - był pojętnym uczniem. Wyrósł na prawdziwego duchowego przywódcę świata.

Biorąc pod uwagę fakt, że niektóre aspekty działalności Jana Pawła II zostaną szerzej omówione w kolejnych wystąpieniach, pragnę jedynie zasygnalizować niektóre obszary, w których zmieniało się oblicze świata dzięki posłudze świętego Papieża. Mam na myśli świat polityki, świat nauki i kultury, świat młodych, świat pracy, świat cierpienia oraz świat miłosierdzia i świętości.

\section{1. Świat polityki}

Jan Paweł II traktował politykę nie jako sztukę zdobywania władzy lub utrzymywania się przy niej, ale jako roztropną troskę o dobro wspólne. Mógłby się podpisać pod słowami papieża Franciszka twierdzącego, że właściwie pojmowana polityka jest najwyższą formą miłości, bo powinna być bezinteresowną służbą drugim. Jan Pawel II zdawał sobie przenikliwie sprawę, jak bardzo nasz świat jest daleki od tego ideału. Jak już wspomniałem, miał osobiste doświadczenie dwóch systemów totalitarnych XX wieku.

Powszechnie uważa się, że Ojciec Święty wniósł niepodważalny wkład w upadek systemu komunistycznego w swojej ojczyźnie i krajach Europy Wschodniej. To była chyba najbardziej widoczna zmiana świata podczas jego pontyfikatu. Jan Paweł II nie dysponował żadną armią w obliczu potęgi, która wydawała się niezniszczalna. Dysponował natomiast słowem prawdy o człowieku, stworzonym przez Boga i powołanym do życia w Bogu na wieki. Nie proponował rewolucji, lecz powrót do prawdy i nawrócenie sumień.

Jan Paweł II uczył, że wobec potęgi siły nie należy uciekać się do przemocy, ale znaleźć „skuteczne formy świadczenia o prawdzie. Taka postawa rozbraja przeciwnika”44. Tak było w przypadku polskiej „Solidarności”. Papież słowem i postawą uruchamiał procesy $\mathrm{i}$ - moglibyśmy powiedzieć - był katalizatorem 
w tych procesach prowadzących do zasadniczych zmian społeczno-politycznych. Ikoną strajku w Stoczni Gdańskiej im. Lenina w 1980 roku był widok robotników modlących się na kolanach, uczestniczących we Mszy Świętej, spowiadających się, a przy nich wizerunek Matki Boskiej Częstochowskiej i duża fotografia Ojca Świętego.

Oczywiście zaangażowanie Jana Pawła II w świecie polityki było znacznie szersze i nie ograniczało się do Europy Środkowo-Wschodniej. Słowo Papieża stawało się niebezpieczne dla dyktatur w innych częściach świata. Jan Paweł II rozmawiał ze wszystkim przywódcami i nigdy nie dowiemy się, ile uczynił dla świata w tym zakresie.

\section{2. Świat nauki i kultury}

Jan Paweł II miał łatwość nawiązywania kontaktów ze wszystkimi ludźmi, ale szczególnie bliskie było mu środowisko uniwersyteckie, ludzie nauki i kultury. To było jego naturalne środowisko jako myśliciela, profesora, pisarza. Tak było w Krakowie, i tak było również podczas pontyfikatu. Jako człowiek Kościoła i jednocześnie człowiek nauki, wniósł ogromny wkład w zakresie wzajemnych relacji między wiarą i nauką. Znamy wielowiekową historię podejrzliwości, uprzedzeń, a nawet wrogich postaw w tym jakże ważnym obszarze życia człowieka. Papież przełamywał uprzedzenia, wychodził naprzeciw.

Jan Paweł II przeszedł do historii jako autor encykliki Fides et ratio, w której w sposób mistrzowski starał się uporządkować świat pojęć i wzajemnych relacji między wiarą i rozumem, wychodząc w ten sposób - w imieniu Kościoła - na spotkanie ludzi ceniących rozum i prawdę, zaangażowanych w poszukiwania naukowe $\mathrm{w}$ różnych obszarach pracy intelektualnej. Już na samym początku encykliki ujawnił swoje spojrzenie i przekonanie o wzajemnej więzi między rozumem i wiarą. Znane są jego słowa: „Wiara i rozum są jak dwa skrzydła, na których duch ludzki unosi się ku kontemplacji prawdy. Sam Bóg zaszczepił w ludzkim sercu pragnienie poznania prawdy, którego ostatecznym celem jest poznanie Jego samego, aby człowiek — poznając Go i miłując - mógł dotrzeć także do pełnej prawdy o sobie"45.

Podczas spotkania ze światem uniwersyteckim w kościele św. Anny w Krakowie, 8 czerwca 1997 roku, składając hołd ludziom nauki, Jan Paweł II ukazał im głębszy wymiar ich powołania i pracy: „Jeżeli dzisiaj, jako Papież, jestem 
tutaj z wami - ludźmi nauki - to po to, aby wam powiedzieć, że współczesny człowiek was potrzebuje. Potrzebuje waszej naukowej dociekliwości, waszej wnikliwości w stawianiu pytań i uczciwości w szukaniu na nie odpowiedzi. Potrzebuje tej swoistej transcendencji, jaka jest właściwa uniwersytetom. Poszukiwanie prawdy, nawet wówczas, gdy dotyczy ograniczonej rzeczywistości świata czy człowieka, nigdy się nie kończy, zawsze odsyła ku czemuś, co jest ponad bezpośrednim przedmiotem badań, ku pytaniom otwierającym dostęp do Tajemnicy!" 46 .

\section{3. Świał młodych}

Na zawsze pozostanie nam w pamięci Światowy Dzień Młodzieży - Kraków 2016. Rzesze młodych chrześcijan z ponad stu osiemdziesięciu krajów, skupionych wokół papieża Franciszka, świętujących swoją wiarę, modlących się, dających świadectwo wyboru Jezusa Chrystusa jako Pana i Zbawiciela oraz świadectwo przynależności do Kościoła. Potężne dzieło ewangelizacyjne, jakim jest każdorazowy Światowy Dzień Młodzieży, jest jedną z najlepszych inicjatyw apostolskich Jana Pawła II. Dlatego dwa lata temu był on tak bardzo obecny w Krakowie w sercach, w modlitwie i radości młodych ludzi, którzy chcieli spotkać się w jego ojczyźnie.

Przez czterdzieści lat mogłem obserwować z bliska spotkania młodych z kardynałem Karolem Wojtyłą, a potem Janem Pawłem II. Trafiał do ich umysłów i serc. Trafiał swoją autentycznością. Trafiał swoją wiarą. Trafiał do nich także wtedy, gdy ustawiał im wysoko poprzeczkę, gdy wymagał, bo przede wszystkim wymagał od siebie. Trafiał do nich, bo im ufał, bo przekonywał ich, że stać ich na wiele i że są potrzebni Kościołowi i światu. Podczas Roku Wielkiego Jubileuszu Roku 2000 nazwał ich „stróżami poranka czuwającymi o świcie trzeciego tysiąclecia” i dodał: „Mówiąc «tak» Chrystusowi, mówicie «tak» wszystkim swoim najszlachetniejszym ideałom. Modlę się, aby On królował w waszych sercach oraz w ludzkości nowego wieku i tysiąclecia. Nie lękajcie się Jemu zawierzyć. On was poprowadzi, da wam siłę, byście szli za Nim każdego dnia i w każdej sytuacji”" ${ }^{4}$. Takimi słowami Jan Paweł II trafiał do serc młodych i dzięki nim zmieniał świat i przygotowywał nowy świat.

\footnotetext{
46 Jan Paweł II, Przemówienie wygłoszone z okazji sześćsetlecia Wydziału Teologicznego Uniwersytetu Jagiellońskiego, Kraków 8 czerwca, kościół św. Anny, nr 4.

47 Por. Jan Paweł II, Rozważanie podczas czuwania modlitwenego, Tor Vergata, „Wy za kogo Mnie uważacie” (Mt 16, 15), Rzym, 19 VIII 2000, nr 6.
} 


\section{4. Świat pracy}

Karol Wojtyła sam doświadczył, czym jest ciężka praca fizyczna, pracując w kamieniołomie i zakładach „Solvay” w Krakowie. Sam był intelektualistą. Był raczej człowiekiem pióra niż kilofa, ale żywił wielki szacunek do pracy fizycznej i do ludzi wykonujących pracę w pocie czoła. Problemowi pracy ludzkiej poświęcił encyklikę Laborem exercens. Dzięki swoim encyklikom społecznym, podobnie jak jego poprzednicy, zbliżył do Kościoła świat pracy, opanowany w znacznej mierze od drugiej połowy XIX wieku przez ideologię marksistowską, z gruntu przeciwną wierze.

Spotykając się 20 czerwca 1983 roku z wiernymi diecezji katowickiej, Ojciec Święty wygłosił homilię, która została nazwana „ewangelią pracy”. Powiedział wtedy: „Praca posiada swoją zasadniczą wartość dlatego, że jest spełniana przez człowieka. Na tym opiera się też godność pracy, która winna być uszanowana bez względu na to, jaką pracę człowiek wykonuje. Ważne jest to, że wykonuje ją człowiek. Wykonując jakąkolwiek pracę, wyciska na niej znamię osoby: obrazu i podobieństwa Boga samego" ${ }^{48}$. Nie ulega wątpliwości, że swoją postawą i nauczaniem Jan Paweł II uwrażliwił Kościół na sprawy świata pracy i zbliżył świat pracy do Chrystusa i Jego Ewangelii.

\section{5. Świat cierpienia}

Jan Paweł II przemawiał na różne sposoby. Przemawiał również do świata osób w podeszłym wieku, cierpiących, chorych, niepełnosprawnych. Zwykle był to i jest świat cichy, milczący, z dala od kamer i mikrofonów. Jan Paweł II użyczył temu ludzkiemu i rozległemu archipelagowi głosu. Uczynił to podwójnie: przez swoje nauczanie oraz przez osobiste cierpienie, osobistą niepełnosprawność i słabość na oczach całego świata. W ten sposób przywrócił godność i nadzieję milionom osób na całym świecie. W ten sposób uwrażliwił świat i zmienił świat w spojrzeniu na los człowieka doświadczającego swoich granic, człowieka słabego, cierpiącego i odchodzącego z tego świata.

W liście apostolskim Salvifici doloris Jan Paweł II pisał: „Skoro więc człowiek idzie poprzez swoje ziemskie życie w taki lub inny sposób drogą cierpienia, zatem Kościół w każdym czasie [...] winien się spotykać z człowiekiem na

${ }_{48} \quad$ Jan Paweł II, Homilia w czasie nabożeństwa maryjnego odprawionego na lotnisku $w$ Muchowcu, Katowice, 20 czerwca 1983, nr 8. 
tej właśnie drodze. Kościół, który wyrasta z tajemnicy Odkupienia w Krzyżu Chrystusa, winien w szczególny sposób szukać spotkania z człowiekiem na drodze jego cierpienia. W spotkaniu takim człowiek staje się «drogą Kościoła» - a jest to jedna z najważniejszych dróg"49.

Niemożliwą rzeczą jest ustalić, jak bardzo Jan Paweł II zmienił świat w spojrzeniu i podejściu do świata cierpienia. Od strony instytucjonalnej stworzył Papieską Radę ds. Duszpasterstwa Służby Zdrowia i ustanowił Światowy Dzień Chorego, obchodzony każdego roku 11 lutego. Swoim nauczaniem, swoimi decyzjami oraz osobistą postawą wobec cierpienia w znacznej mierze zmienił i uwrażliwił świat w tym zakresie.

\section{6. Świat miłosierdzia i świętości}

To ostatni punkt naszej refleksji. Spotykając się z problemami i wyzwaniami, przed jakimi stawał współczesny świat i Kościół, Jan Pawel II patrzył głębiej i szerzej. Patrzył oczami wiary w Boga, który jest Panem ludzkich dziejów, do którego wszystko ostatecznie zmierza. Papież nie ograniczał się do postawienia diagnozy sytuacji świata. Przenikliwie dostrzegał napięcia i konflikty między narodami, nędzę materialną i duchową milionów ludzi. Dostrzegał zagubienie moralne, grzech i zło, ból i rozpacz człowieka. Odpowiedzią było wskazanie drogi nadziei, a było nią i jest miłosierdzie Boga. Papież pochodzący z Krakowa nosił w sobie szczególną wrażliwość w tym zakresie. W ślad za siostrą Faustyną mógł przekonywać Kościół i świat, że „nie znajdzie ludzkość uspokojenia, dopóki nie zwróci się z ufnością do miłosierdzia Boga"so.

Miłosierdzie Boga ma budzić ludzkie miłosierdzie jako dopełnienie sprawiedliwości. Taką drogę miłosiernej miłości wskazywał Jan Paweł II. Taka droga zmienia świat.

W miłości Boga i człowieka, w służbie Kościołowi i światu zajaśniała blaskiem osobista świętość Jana Pawła II, potwierdzona oficjalnie przez jego dwóch następców na Stolicy św. Piotra. Jak pisze papież Franciszek w adhortacji Gaudete et exsultate, „świętość jest najpiękniejszym obliczem Kościoła” Takie oblicze Kościoła ukazał światu św. Jan Paweł II, a jego świętość, wyra-

\footnotetext{
49 Jan Paweł II, List apostolski Salvifici doloris, Watykan 1984, nr 3.

50 F. Kowalska, Dzienniczek, Warszawa 1993, nr 300.

${ }_{51} \quad$ Franciszek, Adhortacja apostolska Gaudete et exsultate, Watykan 2018, nr 9.
} 
żająca się w miłości i służbie, inspiruje innych do kroczenia podobną drogą. Również w ten sposób zmienia się na lepsze świat, w którym żyjemy.

Powróćmy do pytania: Czy Jan Paweł II zamierzał zmienić świat? On przede wszystkim chciał kochać i służyć Bogu i człowiekowi. Temu programowi pozostał wierny do końca. Tym programem inspirował i nadal inspiruje innych. Dlatego zmienił i nadal zmienia oblicze świata.

Dziękuję za uwagę. 
Słowa klucze: Jan Paweł, świat, zmiana oblicza świata, 16 października 1978 roku, biskup Rzymu, wybór, polityka, nauka i kultura, młodzi, świat pracy, chorzy i cierpiący, miłosierdzie

Streszczenie: Wspominając i nawiązując do pamiętnego dnia 16 października 1978 roku, gdy biskup Krakowa stał się biskupem Rzymu, właściwie aż do 2005 roku, dokonało się coś co może nie było wówczas zamierzeniem Jana Pawła II, ale on właśnie dokonał zmiany oblicza świata. Jego pontyfikat bowiem miał niezwykły wpływ na politykę świata, na naukę i kulturę. Niezwykle ważne było odniesienie tego papieża do młodych (organizacja Światowego Dnia Młodzieży), świata pracy, chorych i cierpiących. Jaką̧ś najważniejszą nicią łączącą wszystkie te osoby i obszary życia Kościoła była obecna idea miłosierdzia oraz niezwykle ważne odniesienie do fundamentów życia człowieka. Uzasadniona jest konkluzja, w której czytamy: Czy Jan Paweł II zamierzał zmienić świat? On przede wszystkim chciał kochać i służyć Bogu i człowiekowi. Temu programowi pozostał wierny do końca. Tym programem inspirowat i nadal inspiruje innych. Dlatego zmienił i nadal zmienia oblicze świata.

\section{John Paul II who changed the face of the world}

Key terms: John Paul II, world, change of the face of the world, young people, working people, the sick and suffering, charity

Abstract: When recalling and referring to the memorable date of 16 October 1978 , namely the day on which the Bishop from Cracow became the Bishop of Rome, one should conclude that practically until the year 2005 something had happened which might not have been entirely John Paul II's intention, yet it was his making indeed that he had changed the face of the world. John Paul II's pontificate had a tremendous impact on global politics, science and culture. The especially vital thing was his attitude to the young (organization of the World Youth Day), to working people, to the sick and suffering. Some most important thread tying all of the above people with the spheres of the Church life was the living idea of charity and absolutely crucial references to the foundations of human life. In the above respect the following conclusion seems highly justified: Did John Paul II intend to change the world? First of all he wanted to love and serve God and man. This was the programme which he stayed faithful until the end. This was the programme which inspired and still inspires others. That is why he changed and still changes the face of the world. 